\title{
Instructional Leadership Style and Its Influence on Creation of Conducive Teaching and Learning Environment in Colleges of Education in Zambia.
}

\author{
Sr. Trinity Rose Chikwanda*, Dr Gift Masaiti, Dr Dennis Banda \\ University of Zambia \\ *Corresponding Author: Sr. Trinity Rose Chikwanda, University of Zambia

\begin{abstract}
The article is an extract from the on-going PhD study which was guided by a research question that sought to examine how leadership styles, among them; instructional leadership employed by principals influenced creation of conducive teaching and learning environments in selected Colleges of Education in Zambia. The study employed a survey for quantitative and phenomenology design for qualitative that required to understand the lived experiences of participants. This was used in tandem with mixed method approach. The study was informed by Path-Goal theory and engaged 372 participants and respondents selected purposively and randomly from principals, vice principals, Ministry of Education officials, directors, staff and students. Data protocols among others included semi-structured interviews, focus group discussion, observation, questionnaires and document analysis. Explanatory sequential strategy was used to analyse data guided by interpretivism and positivism paradigms. The findings illuminated that principals' use of instructional leadership style to run their colleges was minimal thus the style had not contributed to creation of conducive teaching and learning environment, instead it had resulted in creation of poor to moderate teaching and learning environments. Principals therefore need to adopt other leadership styles which when combined with instructional would facilitate creation of conducive teaching and learning environments.
\end{abstract}

Key words: Leadership, Instructional leadership, Conducive environment, Teaching and Learning

\section{INTRODUCTION}

Every leader of a learning institution is expected to be an instructional leader and to perform this role effectively. Instructional leadership style is a new phenomenon which developed and gained momentum during the Effective School Movement of the 1980's in the United States. The movement viewed Instructional leadership as primary source of educational expertise, whose aim would be to standardise the practice of effective teaching. Philip (2009) has described instructional leadership as a relatively new concept that emerged in the 1980s and called for a shift in emphasis from institutional leaders being managers or administrators to being instructional or academic leaders. Most leaders who assume leadership roles in learning institutions feel, simply by taking up these positions, they have automatically become instructional leaders.

By definition instructional leadership describes leaders' concern and preoccupation with ensuring that teaching and learning is taking place. The practice of instructional leadership is premised on three dimensions namely 1.Defining the mission 2. Managing instructional programmes and 3.Promoting school climate (Mafumane, 2011, Dongo, 2016). These dimensions when unpacked stipulate functions instructional leaders are obliged to perform in their roles as instructional leaders. These functions can be summarised in the following:

a) Setting academic goals: This involves providing guidance and central theme for the institutional goals.

b) Monitoring achievement levels and evaluating the curriculum.

c) Supervising and evaluating teachers: This entails supervising preparation of lessons and monitoring their implementation and giving feedback on the findings.

d) Protecting Instructional time and progress: This involves respecting and ensuring effective utilisation of time for teaching and learning. 
Instructional Leadership Style and Its Influence on Creation of Conducive Teaching and Learning Environment in Colleges of Education in Zambia.

e) Setting standards for achievement and tone for learning climate: This implies creating and providing a suitable institutional environment which is conducive for teaching and learning.

f) Maximising the effects of instructional organization: This function requires allocating staff and organising resources to maximise effects.

Institutional leaders who perform these functions appropriately are able to record students' growth academically and maximise their performance. To do this, the institutional leader also needsto fulfill certain roles which are pertinent to their work as instructional leaders. These roles required instructional leaders to be:

i) a resource provider: This calls for the leader to be ready to provide resources needed for teaching and learning to take place.

ii) an instructional resource: This requires the leader to be a resource of information on current trends and effective instructional policies which are passed on to the subordinates.

iii) a good communicator: The leader needs to communicate new and essential beliefs regarding learning and teaching. He/she must develop good interpersonal and personal skills with one's subordinates.

iv) a visible presence: This involves physical presence of the leader in an institution so as to have time to focus on learner objectives, modeling learner behavior and designing programmes and activities according to experiences needs.

The four roles and six functions when pulled together result in higher academic performance and a well baked instructional leader.

However, studies conducted in schools (Dongo, 2016, Kabeta, 2015, Mafuwane, 2011) have shown that most school and college leaders were not doing well in their roles as instructional leaders. Philip(2009) argued that instructional leadership was rarely practiced in institutions of learning. His views have been underpinned by Arikewuyo (2009) who also contended that principals in most African states ranked academic and instructional activities such as curriculum development and implementation, teaching and instructional supervision and, lesson observation second to staff and student management. This denotes that leaders in institutions of learning have not taken the core business of their institutions, which is to ensure that learning and teaching is taking place seriously. It has been noted that most leaders of these institutions are more tilted to administration work than what is taking place in class. Philips (2009) and Kabeta(2015) have attributed this attitude to lack of indepth training of principals for their role as instructional leaders. Bush(2007) observed that there was little evidence of institutional leaders being developed for the central function of schools which is to promote learning hence they fall short of conceptualizing their role as leaders of learning. This lack of training affects many areas they are expected to tackle in their roles as instructional leaders. Simui, Mhone and Nkuwa (2011) noted a difference in school heads that followed Educational, Leadership and Management (ELM) course where instructional leadership was taught. The course was introduced in Zambia for head teachers and all in leadership positions in the Ministry of General Education. They observed that leaders who followed the course were doing far much better than those who never received training in that area.

In addition it has been observed by researchers such as Philip (2009) Kabeta(2015) that principals failed to find time in their institutions to execute instructional activities owing to too much paper work they handled as well as their desire to fulfill community's expectations who considered them as managers only. All these negatively affect their performance in instructional leadership. Furthermore, Marks and Printy(2003) and Hallinger (2005) found out that one drawback of instructional leadership was that in many schools the principal was not an educational expert especially in issues to do with the curriculum and often had less expertise than the teachers they supervised. The situation made them fail to perform their role well as instructional leaders.

It is under this background that the research was undertaken to examine principals' practice of instructional leadership and how that practice influenced the creation of conducive teaching and learning environment in two private and two government Colleges of Education in Zambia. 
Instructional Leadership Style and Its Influence on Creation of Conducive Teaching and Learning Environment in Colleges of Education in Zambia.

\section{Statement of Problem And ObJectives}

Instructional leadership style is one of the contemporary leadership styles that most leaders of learning institutions are expected to embrace to improve academic standards and provide quality education in their institutions. Studies conducted by Kabeta (2015) Philip (2009) and Bush (2007) had shown that most institutional leaders failed to apply effectively this leadership style in their various learning institutions. The current study intended to investigate whether or not principals of Colleges of Education used instructional leadership style to run their institutions and how its use influenced creation of conducive teaching and learning environments in their respective colleges. Therefore the study was premised on the objectives below:

1) To examine principals' application of instructional leadership in selected Colleges of Education

2) To determine how the use of instructional leadership style influenced the creation of conducive teaching and learning environments in Colleges of Education in Zambia.

3) To ascertain factors influencing creation of conducive teaching and learning environment under instructional leadership.

\section{Material AND Methods}

Research Design and Sampling: In trying to examine how principals applied their role as instructional leaders in selected Colleges of Education a survey for quantitative approach and phenomenology design for qualitative approach which required getting to know the lived experiences of participants were adopted. This was used in tandem with Mixed Method Approach (MMA). Creswell (2012: 22) defined mixed method approach as "procedures for collecting, analysing and mixing both quantitative and qualitative data in a single study or in a multiphase series of study."The rationale for combining data from qualitative and quantitative approaches was that the approaches provided more insight and understanding of the issue of study that might be missed when only one single research design was used (ibid).In this study explanatory sequential strategy was adopted which required analysing firstly quantitative data whose findings led to supplement the findings with qualitative data. Participants were drawn from top, middle and lower management structures of the college and included students as well as one Ministry of General Education (MoGE) official. Thus, 31 participants were used for interviews and 24 for Focus Group Discussions (FGD) using purposive sampling while 317 were selected using stratified random sampling to answer the questionnaires. The three data collection methods were supplemented by observation and document analysis strategies.

Data Collection Procedure: Data collection started with quantitative data firstly using questionnaires. The shortcomings noted and issues which emerged after data analysis led to conduct qualitative data collection using interviews, focus group discussion, observation and document analysis. The combining of quantitative and qualitative data collection methods facilitated the understanding of the phenomenon under study and precipitated the reliability, authenticity of the findings and generalisation of findings to a larger population.

Data Analysis: Quantitative data from questionnaires were analysed with the help of STATA software (version 14) tool to come up with frequency tables and bar charts. The chi square statistics were used to analyse the association between instructional leadership and creation of conducive teaching and learning environment. The statistical significance was assessed using $\mathrm{P}$ values and all results were considered significant if $\mathrm{P}$ was less than 0.05 .The positivism paradigm was used to interpret data collected and give meaning and objectivity to it. Qualitative data were analysed using thematic approach which involved coming up with themes from the data collected. This was enhanced with the interpretivism paradigm to get meaning from the emerging themes.

\section{FINDINGS AND DISCUSSION}

\subsection{Principals' Not Exercising Instructional Leadership Style}

The investigations on how principals regarded their role as instructional leaders produced responses in the affirmative. Every principal interviewed considered himself/herself as an instructional leader and that they had performed that role meritoriously. Findings from lecturers and students on the same gave negative responses. Out of 96 lecturers who answered the questionnaires, only five (5\%) and 23 (10\%) out of 221 students indicated that principals were instructional leaders as the bar chart below 
presents. This was a small number compared to the total number of people who took part in the study and made the analysis of the leadership style difficult. However the responses by the two groups suggested that principals' perception of instructional leadership was different from their subordinates. These responses especially from lecturers and students established that principals were not exercising their role as instructional leaders as expected, their exercise was very minimal and usually went unnoticed as proved by the small number that recognized that they were instructional leaders.

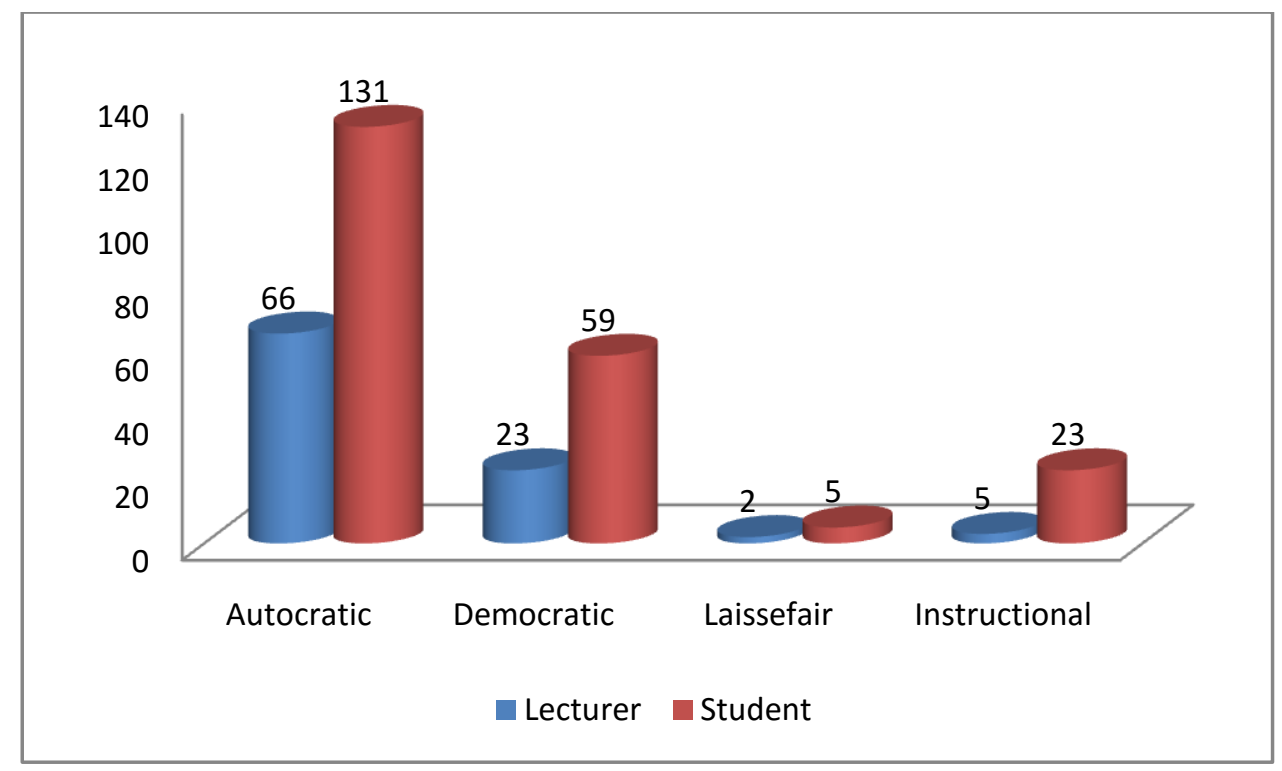

Figure1. Instructional Leadership Style as used by Principals

\subsection{Principals' Ineffective use of Instructional Leadership and Conducive Environment}

To come up with the relationship between instructional leadership and conducive environment, two hypotheses were tested

$\mathrm{H}_{0}$ There is no relationship between instructional leadership and conducive teaching and learning environment

$\mathrm{H}_{1}$ There is a relationship between instructional leadership and conducive teaching and learning environment.

To ascertain the hypotheses certain instructional variables were cross tabulated with friendly atmosphere and collaboration as the main variable to determine conducive environment. The following table gives a synopsis of the findings obtained from that cross tabulation. All the variables examined when cross tabulated gave the Pearson chi square that produced P-values which were above 0.05 as the set alpha significant level. This demystified that all the variables examined were statistically insignificant to contribute to creation of conducive teaching and learning environment in all colleges of study. This explanation rejects the alternative hypotheses and accepts the Null hypotheses which stated that there was no relationship between instructional leadership and creation of conducive teaching and learning environment in the colleges of study. These outcomes of the findings suggest that instructional leadership styles used in colleges of study did not lead to creation of conducive teaching and learning environment based on the figures given in the table below.

Table1. Instructional Leadership and Friendly Atmosphere and Collaboration

\begin{tabular}{|l|l|l|l|}
\hline Variable & Pearson chi2 & df & Asymptotic significance (2 sided) \\
\hline Ensures that curriculum is implemented & $18.135^{\mathrm{a}}$ & 16 & .316 \\
\hline Observes lessons in class & $13.004^{\mathrm{a}}$ & 16 & .672 \\
\hline Provides needed materials for T/L & $20.179^{\mathrm{a}}$ & 16 & .212 \\
\hline Interest in ensuring that T/L is taking place & $9.545^{\mathrm{a}}$ & 16 & .889 \\
\hline Exercises role of instructional leadership & $20.019^{\mathrm{a}}$ & 16 & .219 \\
\hline Leadership improves caliber of training & $16.921^{\mathrm{a}}$ & 16 & .391 \\
\hline
\end{tabular}

The P-value of 0.219 rejected the assertion that principals exercised their role as instructional leaders well. This finding denoted that principals had failed to operate as instructional leaders thus this P- 
value was insignificant to allow principals to apply their role of instructional leadership effectively. The above findings were consolidated by the findings from the questionnaires presented in the bar chart on the next page.

The analysis of the variables in the bar chart highlighted lecturers' observation of their principals' exercise of instructional leadership. On attitude of principals 81 (84\%) of lecturers and 150(68\%) students indicated that principals had a good attitude towards students affairs which was a positive indicator of instructional leadership. A total number of 57(59\%) lecturers and 164 (74\%) students also affirmed that principals had keen interest in ensuring that teaching and learning was taking place in their institutions. These responses portrayed principals' positive application of instructional leadership in their institutions which, it was presumed, contributed to creation of conducive teaching and learning environment.

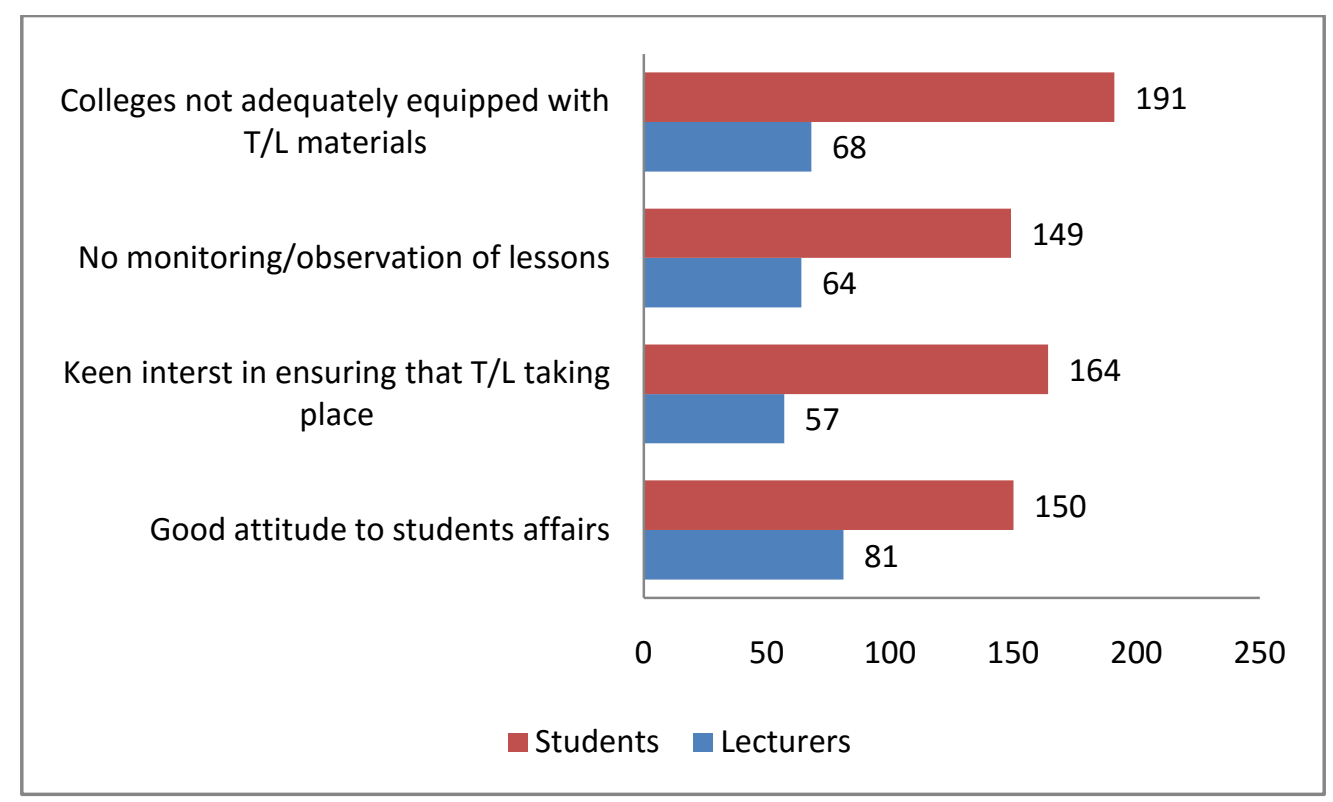

Figure2. Lecturers' and Students' Analysis of Principals' Instructional Leadership

However, this positive attitude was counteracted by both lecturers and student's response on principals' interest in what was taking place in class based on some factors as will be pointed out in the next section.

\subsection{Factors Undermining Instructional Leadership in Colleges}

\subsubsection{Cost of Sporadic Lesson Observation and Monitoring}

Both staff and students bemoaned principals' inability to monitor and observe lessons in class so as to be well acquainted with classroom practices by both students and lecturers. A total number of 149 (67\%) students and 68(71\%) lecturers disagreed that principals monitored and observed lessons as quality assurance measure for effective teaching and learning. Some four out of six lecturers interviewed from government colleges had same responses. These sentiments were echoed during interviews where one respondent categorically pointed out that:

Instructional leadership is non-existent. I have not seen any of the administrators coming to class and give guidance. They rarely come to see what is taking place in class. Their leadership is more administrative that academic.

These sentiments were echoed by many participants from government colleges and corresponded with Philips' (2009) and Kabeta's (2015) findings.

The Lesson observation it was believed brought interaction among three groups that is the principal, lecturer and students. By failing to do so principals were prevented from knowing what was taking place in class so as to provide solutions where necessary. Hallinger and Murphy (1985) asserted that the interaction of the principal with a class of learners provided the principal with more information on the needs of learners and their educator. While private colleges were observed to be monitoring lessons often these observations were made by registrars not principals. Besides it was observed and 
stated by participants from this section that this monitoring was meant for assessment and evaluation of lecturers during renewal of contracts not as quality control measure for effective teaching and learning. Nevertheless, Philip (2009) and Mafuwane (2011) argued that principals as instructional leaders must be practicing teachers so that they know what is going on in class and be able to appreciate challenges teacher educators and students encounter in order to address instructional issues from hands on perspective. Their argument put monitoring and lesson observation to be key factors in principals' exercise of instructional leadership. Hence, principals' failure to carry out this exercise had negative repercussions on the creation of a conducive teaching and learning environment in the college context.

\subsubsection{The Outcome of Scarcity of Teaching and Learning Materials}

The other practice reported and noted in principals was inertia to provide teaching and learning materials. All colleges overwhelmingly condemned principals' lack of provision of teaching and learning materials in their institutions. About 70 (73\%) lecturers and 191(86\%) students who answered questionnaires indicated that principals had not equipped the colleges with the much needed teaching and learning materials in their institutions. Some 8 out of 12 staff interviewed also lamented principals' inertia in providing teaching and learning materials in their colleges. One senior librarian during focus group discussion also intimated that:

Little attention was given to provision of teaching and learning materials. Principals were tilted towards infrastructure development, sports and their trips. Lecturers struggled to get teaching and learning materials. They usually used internet, whose network was often not available, and resorted to using old materials available in their departments. Very little resources were allocated towards buying of teaching and learning materials hence the library had few reference books to be used by both students and lecturers.

These sentiments were suggestive of principals' lack of prioritisation of provision of teaching and learning materials though all principals claimed their mandate to provide teaching and learning materials. About 10 out of 12 students interviewed also echoed same sentiments of lack of teaching and learning materials in their institutions which they said compromised standards in writing assignments and their overall academic performance. Lumadi (2014) upheld the need for teaching and learning resources and alluded that without resources learning content was likely to be presented in a haphazard manner which disadvantaged learners from benefiting from the teaching process. These assertions and observations demonstrated the principals' ineffective prioritisation of provision of teaching and learning materials and hence compromised their instructional leadership role in their institution which had bad influence on creation of a conducive teaching and learning environment. Besides it made them to fail in their role as resource providers.

The insufficient teaching and learning materials in these institutions it was reported was aggravated by principals' habit of starting new programmes without proper planning and adequate funds towards buying of books and other facilities needed. All the colleges studied had expanded programmes to include Early Childhood Education (ECE), Secondary Diploma Programmes and in some cases degree programmes which meant increase in enrolment of students. The expansion had no correspondence increased provision of teaching and learning materials. The few books bought every year and others available were depleted at a fast rate owing to huge number of students in colleges. The new programmes introduced new courses like computer studies and Information Technology and Communication (ICT) which required new facilities but which colleges were grappling to provide. This had made colleges to offer these courses in very difficult situations. In private colleges, it was reported, they had serious problems to offer ICT which had been made compulsory by the government when they did not have computer laboratories with functional computers. The privation of teaching and learning materials in various subjects was a serious hindrance to exercise of instructional leadership as well as creating conducive teaching and learning environment in an institution of learning such as colleges. This finding corresponded with Mafuwanes' (2011) and Dongos' (2016) findings. 
Instructional Leadership Style and Its Influence on Creation of Conducive Teaching and Learning Environment in Colleges of Education in Zambia.

\title{
4.3.3. The Results Of Intermittent Physical Presence In The College
}

The interviews carried out in three colleges indicated frequent absence of principals in their respective colleges. In one college for the three weeks that the researcher was on site the principal was out and was only accessed during the second visit. This long absence had repercussions on how teaching and learning were being conducted during the absence of the principal. In some instances it was reported that both the principal and vice principal would leave the station without leaving any other person to manage the station during their absence. Barrett and Breyer (2016) intimated that effective principals were highly visible in their institutions and focused on making formative observations about learning. The scenario presented above had serious consequences on lecturers' and student attendance to their duties and obligations respectively. In their absence administrators were unable to know how teacher trainers and students behaved to facilitate teaching and learning. The practice worked against the tenets of instructional leadership and hence contributed to negative creation of a conducive teaching and learning environment. Principals in this way were failing in their role to maintain visible presence in their institutions. The practices noted in principals' behaviour had compromised their role as instructional leaders

\subsubsection{Influence of Contextual Factors}

Contextual factors were situations which were found in institutions and which principals could not change on their own. Among the factors noted was over enrollment which had been necessitated by the commencement of new educational programmes as already mentioned. The expansion of programmes did not involve expanding infrastructure. The situation had resulted in over enrollment of students where in one college the number swelled from the normal 350 to over 1000 students. The situation had negative repercussions on teaching and learning environment, teaching methods and general atmosphere in the institution. Some lecturers during FGD expressed their views in the following:

\begin{abstract}
The environment was not conducive for teaching. Infrastructure was insufficient and in some cases dilapidated. The enrolment had increased tremendously but infrastructure had remained the same. Thus some lessons were being conducted under trees and in unfinished buildings. Besides students scrambled for chairs, classes were too large where students stand almost near you. We teach combined classes of about 80-90 students in one small room meant for 40 students. This situation had affected teaching thus some methods of teaching could no longer be used. Learner-centered methods have become difficult to use.
\end{abstract}

The above scenario was prevailing in government colleges and had been accelerated by recruiting parallel classes (extra students recruited to train as external students) who were supposed to learn in the afternoon but were learning side by side with regular students. To create space for this cohort, classes were combined and learning time reduced to 50 minutes per lecture, it was reported and observed. The situation had affected learning and teaching and negatively influenced conducive environment. Principals in this way failed to protect learning time which is one of their functions as instructional leaders.

One teacher trainer lamented teaching 102 students in one class and how he failed to conduct peer teaching or micro teaching which were important exercises of teacher training since he could not create time for each student to practice teaching. Besides, more time was wasted looking for chairs and classroom space while lessons were missed during the rainy season wherever there was a down pour. All these collectively undermined principals' role as instructional leaders. Principals failed to protect teaching time because of such situations in their institutions of learning. This situation compromised instructional leadership hence contributing to creating non-conducive teaching and learning environment in the colleges. This finding tallied with Mafuwanes'(2011) findings who found out that over enrolment compromised practice of instructional leadership as expected.

The other factor examined was infrastructure. The findings from both students and lecturers highlighted that all colleges were facing serious problems of infrastructure. Government colleges, it was reported and observed, were suffering from inadequate and dilapidated classrooms, insufficient and dilapidated hostels as well as bad water and sanitation systems which hindered students from reporting to class in good time. Private colleges too had the same challenges. Both were operating in 
Instructional Leadership Style and Its Influence on Creation of Conducive Teaching and Learning Environment in Colleges of Education in Zambia.

rented premises which did not have all it takes for a place to be called a teacher training college. One college was renting a workshop which did not have conducive rooms for classes, laboratories, office space, hostels and proper sanitation. The other one was renting a house which had two big rooms fit to be a classroom against eight classes while the rest were small rooms. Sanitation was problematic as well as boarding space. The small library was at the same time being used as a classroom thereby depriving students who wanted to use the library any time of the day. Computer laboratory had dysfunctional sockets, and office space was inadequate hence making senior officers share the same office space. For instance during research it was observed in one private college that the principal, vice principal and registrar were sharing same office a situation that compromised confidentiality. These situations compromised conducive teaching and learning environment and made principals fail to create a conducive environment for teaching and learning, a situation that made principals fail in their duties as instructional leaders. This finding converged with Dongo (2016) findings.

The above discussion depicted how instructional leadership role was not well exercised in Colleges of Education, which had consequences on creation of conducive teaching and learning environment. These factors contributed to principals creating non-conducive teaching and learning environments in their respective colleges. The table below gives the overall Pearson chi square of instructional leadership to show if at all it created conducive environment for learning and teaching.

Table2. Chi square Test of Instructional Leadership

\begin{tabular}{|l|l|l|l|}
\hline & Value & df & Asymptotic Significance(2-sided) \\
\hline Pearson Chi-square & $12.1866^{\mathrm{a}}$ & 16 & .731 \\
Likelihood Ratio & 13.563 & 116 & .631 \\
Linear-by-Linear Association & 3.923 & & .048 \\
No of valid cases & 94 & & \\
\hline
\end{tabular}

The chi square test of instructional leadership and creation of conducive teaching and learning environment denoted that the leadership had not contributed to creation of a conducive teaching and learning environment in this study. The chi square P-value of 0.731 is above 0.05 level of confidence showing that the independent variable (instructional leadership) is insignificant and did not have any relationship to create conducive teaching and learning environment perhaps because of the way it was exercised and the factors discussed which had been hindrances to creation of conducive environment. The table below illustrate the type of environment created by the use of instructional leadership style in colleges of study.

Table3. Lecturers' analysis of Instructional Leadership Style and Conducive Teaching and Learning Environment

\begin{tabular}{|l|l|l|l|l|l|l|}
\hline & \multicolumn{2}{|l}{ Low } & Average & High \\
\hline & $\mathrm{f}$ & $\%$ & $\mathrm{f}$ & $\%$ & $\mathrm{f}$ & $\%$ \\
\hline Poor & 3 & 60.00 & 2 & 40.00 & 0 & 0 \\
\hline Moderate & 0 & 0.00 & 1 & 40.00 & 0 & 0.00 \\
\hline Good conducive & 0 & 0.00 & 2 & 40 & 0 & 0.00 \\
\hline Total360 & 24000.00 & \multicolumn{4}{l|}{} \\
\hline
\end{tabular}

The table showed that the three that responded that principals were using instructional leadership indicated that the use produced poor (low) conducive environment while two indicated moderate. This showed that the style produced poor to moderate teaching and learning environments which were not conducive for teaching and learning.

\section{CONCLuSiON}

The findings have illuminated that though principals considered themselves as instructional leaders and believed they were doing so in their work, it had been highlighted that their practice of this leadership style showed very minimal and limited contribution to creation of conducive teaching and learning environment. Their work had been affected by lack of training in this area despite government colleges offering this course under Educational Leadership and Management (ELM) programme. The lack of training coupled with inertia to provide teaching and learning resources, inertia to monitor preparation and implementation of lessons, all had a bearing and implication of providing instructional leadership. This paper also establishes that and frequent absence of principals from their institutions compromised their effective exercise of instructional leadership. Such practices 
Instructional Leadership Style and Its Influence on Creation of Conducive Teaching and Learning Environment in Colleges of Education in Zambia.

made them fail to effectively implement the college curriculum as well as to create a positive climate to ensure that teaching and learning took place. Their inertia to supervise and evaluate instructional programmes had serious effects on curriculum implementation and creation of conducive teaching and learning environment. Working in congested and dilapidated infrastructure and small places had contributed to wasting a lot of time for learning which needed to be protected where effective instructional leadership prevailed. All these factors which bordered on principals behaviour and practices undermined instructional leadership and fit in path-goal theory which stipulates that the behavior of the leader when it motivated subordinates encouraged them to put in the best and thus contributed to good performance. In this case the behavior of principals had impacted negatively on subordinates and thus influenced their performance in their respective institutions.

Clearly even though the academic performance in both categories of colleges was not bad, lecturers and students were working under difficult situations to achieve the current performance. There is surely need for elaborated contributory factors to poor instructional leadership to be addressed. The paper therefore strongly recommends that principals need to work closely with middle management, lower management and students to know what was needed, what was taking place so as to chart the way forward together in improving teaching and learning which was the core business of every institution of learning such as a college. Above all principals needed to know which leadership style should be used side by side with instructional leadership style so that they strengthen their exercise of instructional leadership.

\section{ACKNOWLEDGEMENT}

The researcher would like to thank co-authors of this article as well as all research participants for the information given and for sacrificing their time to take part in this research. To you all many thanks.

\section{REFERENCES}

[1] Philips, J.A., (2009) Manager- Administrator to Instructional Leader: Shift in the Role of the School Principal: Faculty of Education. University of Malaya.

[2] Mafuwane, M.B., (2011). The Contribution of Instructional Leadership to Learner Performance. Pretoria: University of Pretoria (Master Thesis)

[3] Dongo, E., (2016). The Principal's Instructional Leadership Role Towards Creating Effective teaching and Learning. A Case Study of Two High Schools in Ivory Park Township: University of South Africa (Unpublished Material)

[4] Kabeta, M.M.R., (2015). Instructional Leadership and its Effects on the Teaching and Learning Process.A Case of Head teachers in Selected Basic Schools in the Central Province of Zambia. Lusaka: Zambia (Thesis Material)

[5] Arikewuyo, M.A., (2009) Professional Training of Secondary School Principals in Nigeria. A Neglected Area in the Education System. Florida Journal of Educational Administration and Policy, Vol, 2(2)

[6] Bush, T., (2007). Educational Leadership and Management, Theory, Policy and Practice.SA Journal of Education, Vol.27 (3) pp392-406

[7] Simui, F., Mhone, M.,\&Nkhuwa, A.,(2011). A Baseline Study on the Effectiveness of the Head Teacher's Education Leadership and Management Course on Learner Performance. Lusaka: Ministry of Education.

[8] Marks, M.K., \&Printy, M.S., (2003). "Principal leadership and School Performance: An Integration of Transformational and Instructional Leadership." Educational Administration Quarterly Vol.39, No.3 pp 370-399

[9] Hallinger, P., (2005) Instructional Leadership and the School Principal. A Passing Fancy that Refuses to Fade Away. Leadership and Policy in Schools (4), 221-239 DOI 10.1080/15700760500 244793

[10] Creswell, J.M., (2012). Educational Research: Planning, Conducting and evaluating Quantitative and Qualitative Research (4 ${ }^{\text {th }}$ edition.). Boston : Pearson

[11] Hallinger, P., \& Murphy, J., (1985). Assessing the Instructional Management Behavior of Principals: The Elementary School Journal, Vol.86, No.2, pp.217-247.

[12] Lumadi, M.W., (2014). Building a conducive Learning Environment in dysfunctional Schools: A Curriculum Development Tool: Mediterranean Journal of Social Sciences. Vol.5, No.6

[13] Barrett, C., \&Breyer, R., (2014).The Influence of Effective Leadership on Teaching and Learning: Journal of Research Initiatives, Vol.1, Issue. 2 


\section{AUTHOR'S BIOGRAPHY}

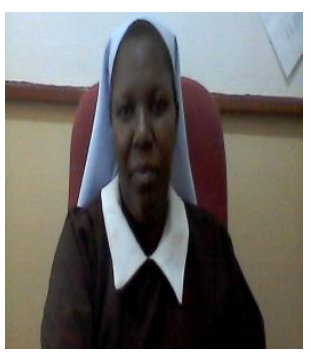

Sr. Chikwanda R. Trinity, is a $\mathrm{PhD}$ student in Educational Administration and Policiy Studies at the University of Zambia. She has a Masters' Degree from Oslo University College (Norway) in International Education and Development. She also holds a Bachelors' Degree from Catholic University of Eastern Africa (CUEA- Kenya) In History and Religious Studies. She is currently a lecturer at Kwame Nkrumah University where she obtained her first diploma in Education. She has a passion for good leadership in institutions of learning hence has conducted research on leadership prevailing in Colleges of Education with the view of improving leadership prevailing in these institutions of higher learning.

Dr Gift Masaiti is assistant Dean in charge of research in the school of Education at the University of Zambia. He is an educationist in economics and management of education with massive experience and networked locally and globally. He has authored a number of journal articles and chapters in various educational publications.

Dr Dennis Banda is assistant Director in the Directorate of Research and Graduate Studies, in charge of research at the University of Zambia. He is an educationist in languages with massive experience in lecturing. He too has authored a number of journal articles and chapters in various educational publications.

Citation: Sr. Trinity Rose Chikwanda, Dr Gift Masaiti, Dr Dennis Banda. "Instructional Leadership Style and Its Influence on Creation of Conducive Teaching and Learning Environment in Colleges of Education in Zambia." International Journal of Humanities Social Sciences and Education (IJHSSE), vol 7, no. 7, 2020, pp. 92-101. doi: http://dx.doi.org/10.20431/2349-0381.0707011.

Copyright: () 2020 Authors. This is an open-access article distributed under the terms of the Creative Commons Attribution License, which permits unrestricted use, distribution, and reproduction in any medium, provided the original author and source are credited. 